\title{
EDITORIAL
}

\section{Time for tocilizumab in COVID-19?}

\author{
Ethan Butler ${ }^{1,2^{*}}$ (B), Marie Warrer Munch ${ }^{3}$ (D) and Balasubramanian Venkatesh ${ }^{4,5}$ (1)
}

() 2021 Crown

Host immune dysregulation is thought to contribute to much of the harm associated with coronavirus disease 2019 (COVID-19) [1, 2]. Accordingly, significant focus has been directed toward finding immunomodulatory therapies to offset this host-mediated damage, leading to the beneficial effects of corticosteroids being demonstrated [3].

As elevated concentrations of interleukin-6 (IL-6) have been found to be an important prognostic factor in COVID-19 [4], attention has also focussed on targeted IL-6 receptor antagonism. Tocilizumab, a recombinant humanised monoclonal antibody, is one such agent. Early observational studies suggested potential benefit with tocilizumab [5, 6], though subsequent randomised control trials (RCTs) demonstrated conflicting results [7-11].

In this rapidly evolving area, much has changed since these initial trials were published. In particular, the landmark RECOVERY [12] and REMAP-CAP [13] platform trials have demonstrated benefit of tocilizumab.

In this issue of Intensive Care Medicine, Snow et al. present a timely and methodologically robust systematic review and meta-analysis of RCTs analysing the effects of tocilizumab in patients with COVID-19 [14], including data from REMAP-CAP [13] and the pre-print of the RECOVERY trial [15], which has since been published in full [12].

The authors included nine RCTs (6493 patients) in the meta-analysis of their primary outcome (mortality at 28-30 days) and found reduced odds of mortality in patients treated with tocilizumab compared to standard care or placebo, but the compatibility interval could not

\footnotetext{
*Correspondence: ethan.james.butler@gmail.com

${ }^{1}$ Department of Intensive Care, Royal North Shore Hospital, St. Leonards, Australia

Full author information is available at the end of the article
}

This article is related to https://doi.org/10.1007/s00134-021-06416-z exclude the possibility of no difference or a small adverse effect at the 5\% significance level (OR 0.87 [95\% compatibility interval (CI) 0.74-1.01]; moderate quality of evidence). The number of patients progressing to the need for mechanical ventilation was also found to be lower in those who received tocilizumab (OR 0.70 [95\% CI $0.54-$ 0.89 ]; very low quality of evidence).

This review raises several important points, some of which are discussed below.

Snow et al. present results for their primary analysis using an odds ratio with random effects with sensitivity analyses using alternate methods (Table 1).

What are we to make of their findings? First, if we look beyond the dichotomisation of p-values, we can see that the data is both consistent and far more compatible with benefit than with harm, regardless of the underlying statistical assumptions made. Second, the results of the trial sequential analysis (TSA) of the primary outcome cross the 'futility boundary' (an estimated threshold below which an intervention is unlikely to have an important effect) suggesting enrolling further patients is 'futile'. Of note, this reflects the current parameters of the TSA (i.e., a relative risk reduction (RRR) of $15.7 \%$, with a large typeII error rate of 20\%). It is plausible that a smaller benefit exists (e.g. RRR 5-10\%) which is still clinically important, however, the required information size (the number of patients needing to be included to detect an anticipated intervention effect with sufficient power) would be significantly larger than currently presented.

In the RECOVERY trial [14], mortality was lower for the subset of patients who received both tocilizumab and corticosteroids (OR 0.79, 95\% CI 0.70-0.89). However, in patients who received tocilizumab without corticosteroids, there was a wide range of possible effects (OR $1.16,95 \%$ CI $0.91-1.48$ ), though the data is more compatible with harm. Similarly, in the REMAP-CAP trial [13] ( $>90 \%$ receiving corticosteroids), a mortality benefit was reported with tocilizumab in addition to corticosteroids (OR 0.70 [95\% CI 0.52- 0.96]). While these trials would

\section{Springer}


Table 1 Results of the meta-analysis by Snow et al. with sensitivity analyses for the primary outcome (mortality at 28-30 days)

\begin{tabular}{llc}
$\begin{array}{l}\text { Statistical analysis of primary out- } \\
\text { come (mortality at 28-30 days) }\end{array}$ & Effect size & $\begin{array}{c}\mathbf{9 5 \%} \text { Compat- } \\
\text { ibility interval }\end{array}$ \\
\hline Odds ratio (random effects)* & OR 0.87 & $0.74-1.01$ \\
\hline Odds ratio (fixed effects) & OR 0.85 & $0.76-0.96$ \\
Relative risk (random effects) & RR 0.89 & $0.82-0.96$ \\
Relative risk (fixed effects) & RR 0.89 & $0.83-0.97$ \\
\hline
\end{tabular}

*Authors' primary analysis

seem to indicate an interaction between the two drugs, this was not explored via subgroup analyses or metaregression in the review by Snow et al. [14]. It would also be prudent to note that the smaller TOCIBRAS trial [11] had a similar level of corticosteroid use as REMAP-CAP [13] and RECOVERY [15], but was stopped early for possible harm.

Consideration must also be taken of the study populations. The REMAP-CAP [13] and RECOVERY [15] trials enrolled predominately white men from western European and North American regions, with the RECOVERY trial [15] signalling subgroup effects for gender and ethnicity. While the TOCIBRAS trial [11] was stopped early for possible harm in a Brazilian cohort, the EMPACTA [8] trial reported reduced likelihood of progression to mechanical ventilation in underserved and racial and ethnic minority populations. Additionally, the meta-regression by Snow et al. also suggests some association of illness severity with tocilizumab, although the treatment effect is not reported in subgroups of patients receiving different levels of respiratory support. It is important to note that these subgroup analyses exploring possible heterogeneity of treatment effect have low power, are prone to false positives and should generally be considered exploratory. Moreover, six trials included in the metaanalysis were open-label raising the possibility of added bias.

It is evident that the evidence of benefit on mortality and progression to need for mechanical ventilation with tocilizumab reported by Snow et al. needs to be interpreted with caution. Tocilizumab appears to improve these outcomes when combined with corticosteroids. However, the magnitude of this effect and the subgroups of patients who will benefit most remains to be fully clarified. Moreover, in the RECOVERY trial [15], almost two-thirds of the patients not mechanically ventilated at randomisation, who subsequently died, did not receive mechanical ventilation, clouding the interpretation of this secondary endpoint.
Whether tocilizumab is beneficial in the absence of corticosteroids is also unclear. However, given the convincing evidence for corticosteroids already, which now constitutes 'standard care', an adequately powered trial investigating this is unlikely to occur.

Whilst there was no strong evidence for increased serious adverse events across the included trials, the RECOVERY trial [15], which contributes the bulk of available data, did not routinely report on the adverse effects of tocilizumab.

Other unanswered questions include the optimal timing and dose of tocilizumab, and whether therapy should be guided by biomarkers (e.g., IL-6 or c-reactive protein concentrations). Additionally, there is not enough data for other IL-6 receptor antagonists, such as Sarilumab, to determine whether the benefit seen with tocilizumab is a specific drug or a class effect.

While further high-quality trials would be useful to clarify these points, carefully planned individual patient data meta-analyses may offer a cost-effective way of reducing this uncertainty and potentially exploring subgroups who would benefit most [16].

\begin{abstract}
Author details
${ }^{1}$ Department of Intensive Care, Royal North Shore Hospital, St. Leonards, Australia. ${ }^{2}$ Northern Clinical School, Sydney Medical School, University of Sydney, Sydney, Australia. ${ }^{3}$ Department of Intensive Care, Rigshospitalet, University of Copenhagen, Copenhagen, Denmark. ${ }^{4}$ Professor of Intensive Care, The Wesley Hospital, University of Queensland, Brisbane, Australia. ${ }^{5}$ The George Institute for Global Health, University of New South Wales, Sydney, Australia.

\section{Funding}

EB, MWM and BV declared no funding for any aspect of this study.

\section{Declarations}

\section{Conflicts of interest}

EB declares no conflicts of interest. MWM is the coordinating investigator of the 'Higher vs Lower Doses of Dexamethasone in Patients with COVID-19 and Severe Hypoxia (COVID STEROID 2) trial' (NCT04509973). BV is part of the Management Committee of the COVID STEROID 2 trial.
\end{abstract}

\section{Publisher's Note}

Springer Nature remains neutral with regard to jurisdictional claims in published maps and institutional affiliations.

Received: 13 April 2021 Accepted: 19 May 2021

Published online: 31 May 2021

References

1. Fajgenbaum DC, June CH (2020) Cytokine Storm. N Engl J Med 383:2255-2273

2. Tay MZ, Poh CM, Rénia L, MacAry PA, Ng LFP (2020) The trinity of COVID-19: immunity, inflammation and intervention. Nat Rev Immunol 20:363-374

3. The WHO Rapid Evidence Appraisal for COVID-19 Therapies Working Group (2020) Association between administration of systemic corticosteroids and mortality among critically III patients with COVID-19: a metaanalysis. JAMA 324:1330-1341 
4. Del Valle DM, Kim-Schulze S, Huang H-H, Beckmann ND, Nirenberg S, Wang B, Lavin Y, Swartz TH, Madduri D, Stock A, Marron TU, Xie H, Patel M, Tuballes K, Van Oekelen O, Rahman A, Kovatch P, Aberg JA, Schadt E, Jagannath S, Mazumdar M, Charney AW, Firpo-Betancourt A, Mendu DR, Jhang J, Reich D, Sigel K, Cordon-Cardo C, Feldmann M, Parekh S, Merad M, Gnjatic S (2020) An inflammatory cytokine signature predicts COVID19 severity and survival. Nat Med 26:1636-1643

5. Guaraldi G, Meschiari M, Cozzi-Lepri A, Milic J, Tonelli R, Menozzi M, Franceschini E, Cuomo G, Orlando G, Borghi V, Santoro A, Di Gaetano M, Puzzolante C, Carli F, Bedini A, Corradi L, Fantini R, Castaniere I, Tabbì L, Girardis M, Tedeschi S, Giannella M, Bartoletti M, Pascale R, Dolci G, Brugioni L, Pietrangelo A, Cossarizza A, Pea F, Clini E, Salvarani C, Massari M, Viale PL, Mussini C (2020) Tocilizumab in patients with severe COVID-19: a retrospective cohort study. Lancet Rheumatol 2:e474-e484

6. Gupta S, Wang W, Hayek SS, Chan L, Mathews KS, Melamed ML, Brenner SK, Leonberg-Yoo A, Schenck EJ, Radbel J, Reiser J, Bansal A, Srivastava A, Zhou Y, Finkel D, Green A, Mallappallil M, Faugno AJ, Zhang J, Velez JCQ, Shaefi S, Parikh CR, Charytan DM, Athavale AM, Friedman AN, Redfern RE, Short SAP, Correa S, Pokharel KK, Admon AJ, Donnelly JP, Gershengorn HB, Douin DJ, Semler MW, Hernán MA, Leaf DE, Investigators S-C (2021) Association between early treatment with tocilizumab and mortality among critically III patients with COVID-19. JAMA Intern Med 181:41-51

7. Hermine O, Mariette X, Tharaux PL, Resche-Rigon M, Porcher R, Ravaud $P$ (2021) Effect of tocilizumab vs. usual care in adults hospitalized with COVID-19 and moderate or severe pneumonia: a randomized clinical trial. JAMA Intern Med 181:32-40

8. Salama C, Han J, Yau L, Reiss WG, Kramer B, Neidhart JD, Criner GJ, Kaplan-Lewis E, Baden R, Pandit L, Cameron ML, Garcia-Diaz J, Chávez V, Mekebeb-Reuter M, Lima de Menezes F, Shah R, González-Lara MF, Assman B, Freedman J, Mohan SV (2020) Tocilizumab in patients hospitalized with Covid-19 pneumonia. N Engl J Med 384:20-30

9. Salvarani C, Dolci G, Massari M, Merlo DF, Cavuto S, Savoldi L, Bruzzi P, Boni F, Braglia L, Turrà C, Ballerini PF, Sciascia R, Zammarchi L, Para O, Scotton PG, Inojosa WO, Ravagnani V, Salerno ND, Sainaghi PP, Brignone A, Codeluppi M, Teopompi E, Milesi M, Bertomoro P, Claudio N, Salio M, Falcone M, Cenderello G, Donghi L, Del Bono V, Colombelli PL, Angheben A, Passaro A, Secondo G, Pascale R, Piazza I, Facciolongo N, Costantini M (2021) Effect of tocilizumab vs. standard care on clinical worsening in patients hospitalized with COVID-19 Pneumonia: a randomized clinical trial. JAMA Intern Med 181:24-31

10. Stone JH, Frigault MJ, Serling-Boyd NJ, Fernandes AD, Harvey L, Foulkes AS, Horick NK, Healy BC, Shah R, Bensaci AM, Woolley AE, Nikiforow S, Lin N, Sagar M, Schrager H, Huckins DS, Axelrod M, Pincus MD, Fleisher J, Sacks CA, Dougan M, North CM, Halvorsen Y-D, Thurber TK, Dagher Z, Scherer A, Wallwork RS, Kim AY, Schoenfeld S, Sen P, Neilan TG, Perugino CA, Unizony SH, Collier DS, Matza MA, Yinh JM, Bowman KA, Meyerowitz E, Zafar A, Drobni ZD, Bolster MB, Kohler M, D'Silva KM, Dau J, Lockwood MM, Cubbison C, Weber BN, Mansour MK (2020) Efficacy of tocilizumab in patients hospitalized with Covid-19. N Engl J Med 383:2333-2344

11. Veiga VC, Prats JAGG, Farias DLC, Rosa RG, Dourado LK, Zampieri FG, Machado FR, Lopes RD, Berwanger O, Azevedo LCP, Avezum Á, Lisboa TC, Rojas SSO, Coelho JC, Leite RT, Carvalho JC, Andrade LEC, Sandes AF, Pintão MCT, Castro CG, Santos SV, de Almeida TML, Costa AN, Gebara OCE, de Freitas FGR, Pacheco ES, Machado DJB, Martin J, Conceição FG, Siqueira SRR, Damiani LP, Ishihara LM, Schneider D, de Souza D, Cavalcanti AB, Scheinberg P (2021) Effect of tocilizumab on clinical outcomes at 15 days in patients with severe or critical coronavirus disease 2019: randomised controlled trial. Br Med J 372:84

12. The Recovery Collaborative Group (2021) Tocilizumab in patients admitted to hospital with COVID-19 (RECOVERY): a randomised, controlled, open-label, platform trial. The Lancet 397:1637-1645

13. The REMAP-CAP Investigators (2021) Interleukin-6 receptor antagonists in critically III patients with COVID-19. N Engl J Med 2021(384):1491-1502

14. Snow TAC, Saleem N, Ambler G, Nastouli E, Singer M, Arulkumaran N (2021) Tocilizumab in COVID-19: a meta-analysis, trial sequential analysis, and meta-regression of randomized-controlled trials. Intensive Care Med. https://doi.org/10.1007/s00134-021-06416-z

15. Horby PW, Pessoa-Amorim G, Peto L, Brightling CE, Sarkar R, Thomas K, Jeebun V, Ashish A, Tully R, Chadwick D, Sharafat M, Stewart R, Rudran B, Baillie JK, Buch MH, Chappell LC, Day JN, Furst SN, Jaki T, Jeffery K, JuszCzak E, Lim WS, Montgomery A, Mumford A, Rowan K, Thwaites G, Mafham M, Haynes R, Landray MJ (2021) Tocilizumab in patients admitted to hospital with COVID-19 (RECOVERY): preliminary results of a randomised, controlled, open-label, platform trial. Medrxiv 4:2021.2002.2011.21249258

16. Riley RD, Lambert PC, Abo-Zaid G (2010) Meta-analysis of individual participant data: rationale, conduct, and reporting. Br Med J 340:221 